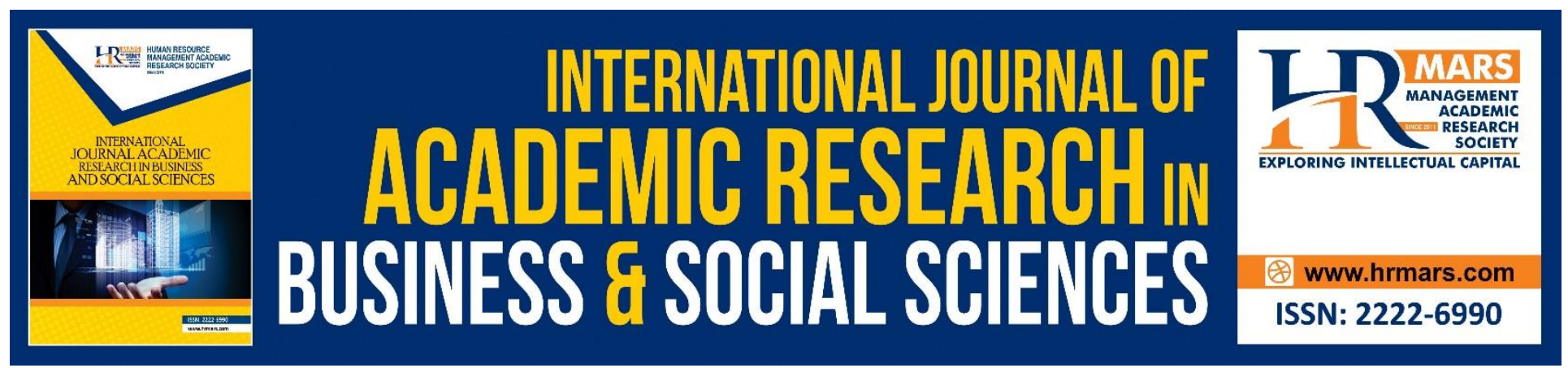

\title{
Influences of Facebook Advertisement on the Buying Behavior of Youth Groups: A Comparative Study of Bangladesh and Turkey
}

\author{
Md. Aslam Uddin, Abdur Rob Razu
}

To Link this Article: http://dx.doi.org/10.6007/IJARBSS/v9-i2/5578

DOI: $\quad 10.6007 /$ IJARBSS/v9-i2/5578

Received: 11 Jan 2019, Revised: 18 Feb 2019, Accepted: 25 Feb 2019

Published Online: 04 March 2019

In-Text Citation: (Uddin \& Razu, 2019)

To Cite this Article: Uddin, M. A., \& Razu, A. R. (2019). Influences of Facebook Advertisement on the Buying Behavior of Youth Groups: A Comparative Study of Bangladesh and Turkey. International Journal of Academic Research in Business and Social Sciences, 9(2), 433-448.

Copyright: (C) 2019 The Author(s)

Published by Human Resource Management Academic Research Society (www.hrmars.com)

This article is published under the Creative Commons Attribution (CC BY 4.0) license. Anyone may reproduce, distribute, translate and create derivative works of this article (for both commercial and non-commercial purposes), subject to full attribution to the original publication and authors. The full terms of this license may be seen at: http://creativecommons.org/licences/by/4.0/legalcode

Vol. 9, No. 2, 2019, Pg. 433 - 448

http://hrmars.com/index.php/pages/detail/IJARBSS

JOURNAL HOMEPAGE

Full Terms \& Conditions of access and use can be found at http://hrmars.com/index.php/pages/detail/publication-ethics 


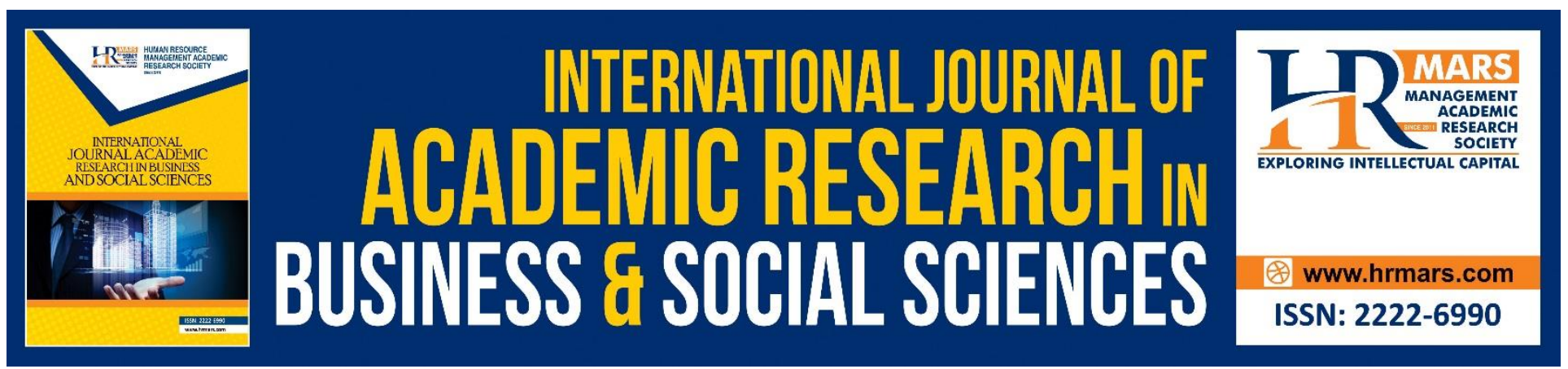

\title{
Influences of Facebook Advertisement on the Buying Behavior of Youth Groups: A Comparative Study of Bangladesh and Turkey
}

\author{
Md. Aslam Uddin \\ Assistant Professor and Chairman (Acting), Department of Marketing, Bangladesh University of \\ Business and Technology (BUBT), Dhaka, Bangladesh \\ Email: aslam@bubt.edu.bd
}

Abdur Rob Razu

Gazi University, Ankara, Turkey

Email: robrazu@yahoo.com

\begin{abstract}
Last couple of years, the growing activities of social media is incredibly dominating over television and the internet has been created a new advancement of business opportunities. For instance, social media has made as online communities for the youth groups. The available internet facilities have made people to use social media particularly Facebook for interacting each other without the need for physical appointment. This paper is predominantly endeavored to analyze and identify the influential factors of Facebook advertisement on the buying behavior of youth groups of Bangladeshi and Turkey consumers. Using descriptive statistics and Factor Analysis, the paper identifies and discusses mainly five important factors that influence two countries' youth groups in purchasing products and services advertised on Facebook. These analyses indicate that Facebook advertisings on the buying behavior of both countries are positive. The paper also discusses implications for retail brand managers about how to make effective Facebook advertisements.
\end{abstract}

Keywords: Facebook Advertisements, Youth Purchasing Behavior, Social Media,

\section{Introduction}

Effective communication is probably the most important factors for developing customer's behavior and retaining them for a long time towards any specific product or service. Demand and making quality advertisements remain a big concern for decades over the world. In recent years, the internet has been created a new advancement of business opportunities. For example, social media has made as online communities (Armstrong and Harker), 2009). Now, individuals can spontaneously access 
and share information with the help of emerging social media and online communities (Meenaghan, 1991). The availability of internet has given the opportunity to the people to use social media and Facebook is one of the medium has made to interact with people without the need for physical appointment (Chang and Krosnick, 2009). Last couple of years, the growing activities of social media is incredibly dominating over television. To reach out 50 million audiences' radio had to spend more than 30 years while television reached out this amount in 13 years. Surprisingly, internet had managed to embrace this amount just only four years, Facebook along touched this milestone just only one and half years (Karrh et al., 2003, Bueß, 2004, Argan et al., 2007)

According to Facebook statistics (January, 2018) Facebook has more than 2.07 billion monthly active users which is a $16 \%$ rise year over year. There are approximately 1.28 billion people log onto Facebook daily which is a $17 \%$ rise year over year. In addition, around 1.37 billion people access Facebook daily by mobile phone which is a $16 \%$ rise from last year. Surprisingly, $50 \%$ of in between 18-24 year-olds go on Facebook when they wake up (Zephoria, January 2018). Facebook is a very popular social networking site amid young group, it is calculated roughly that around $76 \%$ young generation in between (18-34), are the prime users of Facebook (Lehu, 2007). (Su, 2010) described that more than 56.9 million of total of 71.4 million of Spanish-language users on Facebook are under 35 years. Previous studies showed that young group is very much keen on to join social networking sites to keep touch with friends\& family even make new friends and meet new people on online (Přikrylová and Jahodová, 2010). In Bangladesh, Dhaka is the second largest city in terms of having the most active Facebook with $1.1 \%(22,000,000)$ of the total monthly active users of the social networking site across the world. Whereas one of the most popular city in the world Istanbul is on number eight with .6\% of total monthly users of Facebook. But along in Turkey is in the number eight position on the globe, which is $2 \%(48,000,000)$ while first position is USA with $11 \%(219,000,000)$ active users in Facebook (Murad, 2017). In addition, Young generation in Turkey is greatly embraced with social media; three out of ten internet users are between 18 and 24 years of age in Turkey. Whereas other countries in their research; Russia, Poland, Romania, Belarus and Ukraine two out of ten internet users (Global, 2015).

According to (Su, 2010) there is no option to deny that youths are the prime users of Facebook. Therefore, Facebook is becoming a lucrative channel to place the advertisements for youth group. Over the years, many studies have been conducted about this aspect in different countries, but no research has done yet between Bangladesh and Turkey. Considering the huge marketing prospective, flourishing usage and comprehensive evolvement of Facebook in both countries Turkey and Bangladesh, this study is designed to seek the influence of Facebook advertisement on the buying behavior of youth group between Bangladesh and Turkey.

\section{Literature Review}

The correlation between individuals has enlarged on the internet because of the internet's progression and the great improvement of Web 2.0. This advancement enables customers as well as marketers to collaborate themselves on the internet (Häckner and Nyberg, 2008). In addition, online social network sites change the thoughts of marketing and enable the companies and consumer's straight interaction and relationship with each other (Robin et al., 333). For instance, Facebook is one 
of the most vital social networking sites for these activities. Facebook was initially designed to communicate within a certain area, only for Harvard students and the website launched by Mark Zuckerberg on February 4, 2004. Facebook is a common platform to create personal profile, share individual's thought by status, messaging to friends and family and so on. Just after few years, the website has become one the most popular social networking site in the world. Facebook actually permits users to post pictures, videos, customize their profile content and to share their personal thoughts towards an object or particular issue. (Idris, 2017) made a research on "The benefits of Facebook friends: Social capital and college students' use of online social network sites" had illustrated that people use facebook to interact with other they already know offline or to make new friends by adding them friend on their friend list. Facebook has made an opportunity to make personal profile by which ones present themselves on virtual era. According to (Ahmed, 2018) Facebook gave a greater platform for youth group to share their emotions, personal view towards an object or particular issue by put on their comment.

\section{Youth Purchasing Behavior}

Input, process and output are the three stages of consumer purchasing behavior by which one decide to buy the product. Which product consumer will decide to purchase depends on both formal and informal sources of information. Marketers can internally provide information to the consumer by using four $\mathrm{P}^{\prime} \mathrm{s}$ of marketing, whereas external information can be collected through some informal sources such as; friends, family or words of mouth. In the processing stage information is blending with experience, knowledge, perceptions and cultural norms and belief of a customer. Output stages are involved with two sub-stages as post purchase and post purchase evaluation (Schiffman and Kanuk, 2004). In selection of buying behavior of Facebook advertisements, consumers can receive information regarding particular product or service both from internal and external sources, processing of information is also easy due to the presence of available information on facebook and easy to compare and select between two same categorized products. According to (Watch, 1992) youth is deliberated a very crucial segment of market due to their continuous access on internet to find out necessary information and prudent judgment of it make them significant consumer segment. According to (Macgregor, 2004) today's youth are not only more confident to consume only for themselves, but also can influence their family for purchase decision. As compare to previous generation today's youth are more confident and independent consumers due to their frequent access on digital and internet arena and ability to influence other. According to (Chulasiriwongs, 2001) described if company wants to get major market share in future, there is only way to achieve the goal by targeting youth group as a major segment. In addition, in the recent era, youth group are more concerned about technology. They use various social networking sites as Facebook, twetter etc., they are self innovators to find out their desired things and like to make online transactions (Ernst and Young, 2012)

\section{The Advantages of Facebook as a Platform of Advertising}

According to (George, 2016) Facebook Advertisements can reach more audiences at a time and through Facebook Ads it's quite easy for marketers to find out their desire target group. A Facebook ad is considered one of the easiest ways to advertise. In this case, previous experiences of marketing 
are not needed to start Facebook Ads. In addition, marketers do not need to set up big budget to place their ads on Facebook. Because of the cost of Facebook ads is as cheap as five dollars. Mark Zuckerberg, the founder and Chief Executive Officer (CEO) of Facebook, Explained the importance of Facebook advertising, "It's no longer just about message that are broadcast out by companies, but increasingly about information that is between friends. So we set out to use these social actions to build a new kind of ad system" cited in (Piskorski et al., 2010). Indicating the advantage of Facebook advertising, (Manning-Schaffel, 2009) illustrates that: "The ease of creating content makes it so that we get very high engagement, far beyond typical page views. It also gives us a great platform to listen to the feedback we receive from our consumers. Every time we post photos, videos or status updates from the page, our fans are quick to tell us what they think. Their feedback is shared with their network of Facebook friends, exposing them to our fan page". Upholding the above statements, (Manning-Schaffel, 2009) described that "Facebook helps us get a pulse on what is important to our customers. We can have a real dialogue with them about the values and ideas that they share with us". In line with the above affirmation, "Facebook is an effective marketing platform because networking and communication are already taking place. This allows companies to be directly woven into conversation simply by appearing on the site" (Eriksson). "One of the key advantages to Facebook and other similar platform is measurability. Companies are able to actually measure the performances of their communication on a near moment-by-moment basis. It allows advertisers to better understand their customers, and target their respective audiences more effectively, while incurring less advertising waste, thereby managing their resources more efficiently" (Solaja and Odiaka, 2010). Facebook automatically choose key words or details of targeted customer group to run Facebook advertisements such as relationship status, interest, place, activities, preferred books and employment even which page or website people visit more and then Facebook drives the advertisements on the basis of these. For example, if someone likes cupcakes, inhabit a definite neighborhood and have invited friends over, anticipate an advertisement from a neighboring bakery to come into sight on their page (Andrews, 2012).

\section{Research Questions}

The current study aims to fill the research gap in the literature by investigating the following important research questions:

a) What are the important factors that influence youth groups to purchase products and services advertised on Facebook?

b) What are the factors that motivate only Bangladeshi consumers to choose products and services promoted on Facebook?

c) What are the factors that stimulate only Turkey consumers to take products and services advertised on Facebook?

d) What are the similarities and differences between influential factors based on two different countries? And

e) What are the guidelines for online advertising (FB ad) strategy formulation?

Answers to these questions are likely to be significant to the brand managers and advertisers of multinationals operating in Bangladesh and Turkey but also to the local businesses in terms of 
INTERNATIONAL JOURNAL OF ACADEMIC RESEARCH IN BUSINESS AND SOCIAL SCIENCES

Vol. 9, No. 2, Feb, 2019, E-ISSN: 2222-6990 C 2019 HRMARS

understanding of the dynamics of making effective communications strategies for attracting online consumers.

\section{Objective of the study}

The objective of this study is to investigate the factors that influence the youth groups to purchase products and services advertised on Facebook and to examine similarities and differences of influential factors among two countries consumers.

\section{Methodology of the study}

The study group has taken into account of young consumers in Turkey and Bangladesh who have various demographic and socio-economic features and especially use Facebook. The study group is pretty large, total 318 participants filled up the questionnaire, among them 168 Bangladeshi participants and 150 Turkish. In this research data were collected from two sources, one was primary data that were collected from survey where participants were from the different professions but especially from the university students. Survey questionnaire were made in Google docs' service and paper made also, online questionnaire were created to ensure random participation from all over the country. Secondary data were collected from various research publications, books, internet etc. The Likert scale was used to assess the youth's buying behavior in Bangladesh and Turkey and close-ended questions were also used to collect demographic data about the youth groups. The questions were graded from Strongly Disagree to Strongly Agree on a five point Likert scale. Those who were within the age range of 18-35 were considered as the target population for this research for observing the common scenario of youth buying behavior upon Facebook Advertisements. SPSS 16.0 package program was used to analyze research data and descriptive statistics was conducted to observe demographic information, comparative frequency of two different countries consumer behavior on Facebook advertisement were employed to analyze the primary data.

Factor analysis was also used to observe the most influential factors for the buying behavior of youth groups about the products and services advertised on Facebook. The scale was prepared with 19 items. Factor analysis was used to determine the structure validity of the scale. According to the results of the Principal Components Analysis, Kaiser-Meyer Olkin (KMO), the value is found to be 0.928 for Bangladesh and 0.936 for Turkey. The value found using the Bartlett test $(1.842 \mathrm{E} 3,2.029 \mathrm{E} 3$, for two countries respectively, $\mathrm{df}=171$ for both) is significant $(\mathrm{p}<.001)$. The KMO value over 0.60 and significant result of the Bartlett test show that factor analysis is appropriate to be done for this study (Wallén, 1996).

\section{Data Analysis, findings and Discussion}

The questionnaire was sent out to the people through social network like Facebook and documented question paper handed in person to person, where 168 Bangladeshi people and 150 Turkish people filled in the questionnaire. Questionnaire was made by using Google Doc File for online survey and documented question paper for personal interview. 
INTERNATIONAL JOURNAL OF ACADEMIC RESEARCH IN BUSINESS AND SOCIAL SCIENCES

Vol. 9, No. 2, Feb, 2019, E-ISSN: $2222-6990$ ๑ 2019 HRMARS

Descriptive statistics

Table 1: Comparative Frequency Table of Two Different Countries Consumer Behavior on Facebook Advertisement

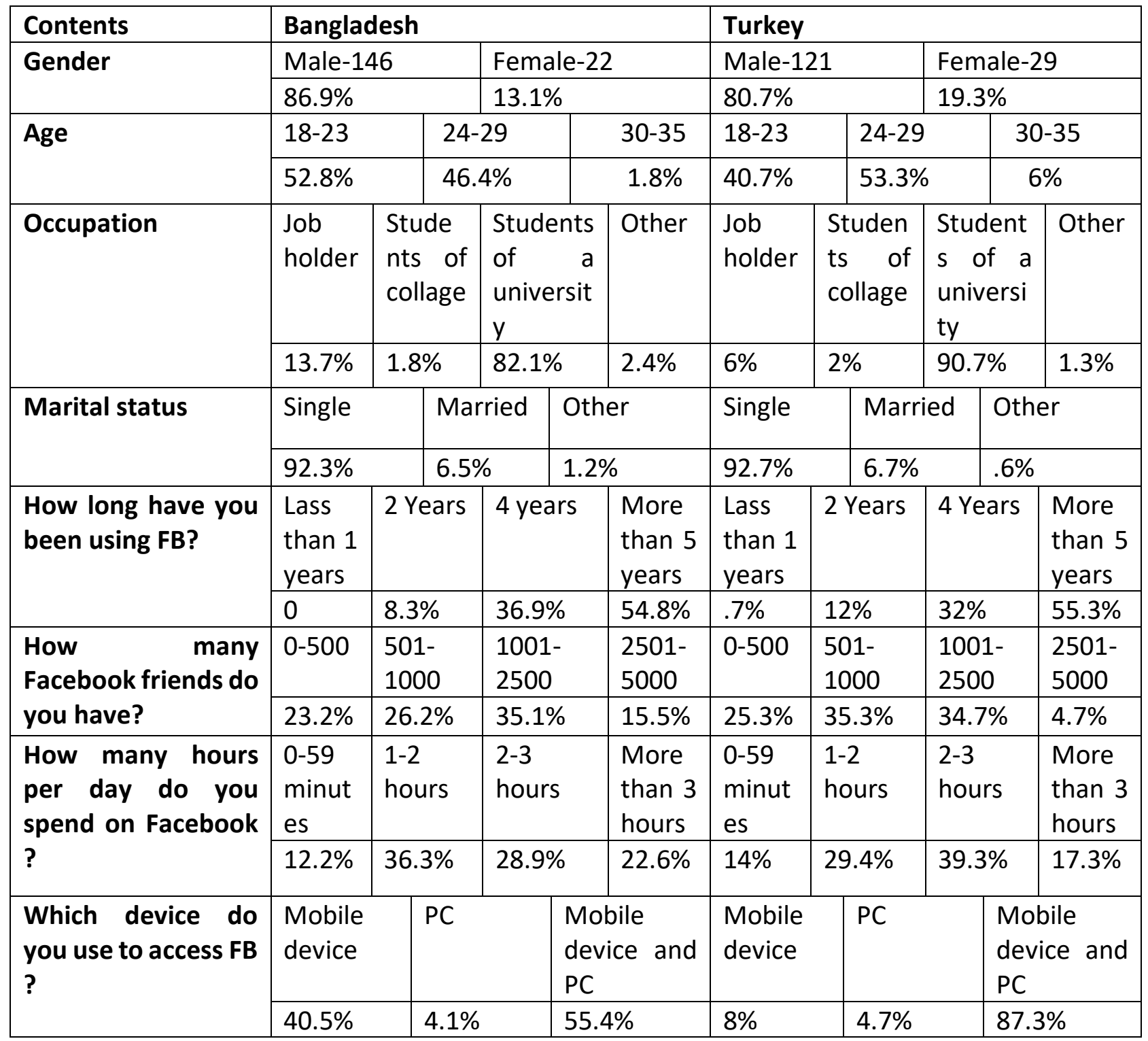

In Bangladesh and Turkey maximum respondents were young group and male participants were about four times higher than female. $51.8 \%$ in between $18-23$ aged and $46.4 \%$ in between $24-29$ aged in Bangladesh. Whereas, in Turkey, $40.7 \%$ are in between $18-23$ aged and $53.3 \%$ are in between $24-$ 29 aged and rest percentages are other aged group. The occupation of the respondents at the Students of a University in Bangladesh $82.1 \%$, Job holder $13.7 \%$, Students of collage was $1.8 \%$ and other only $2.4 \%$ respectively. In Turkey, the respondents at the Students of a University $90.7 \%$ and rest of others are different professional group. The Marital status of the Bangladeshi respondents and Turkish respondents are more or less similar 92.3\% single in Bangladesh while Turkey $92.7 \%$ and 
rest others are different marital status group. 54.8\% respondents are using FB more than 5 years in Bangladesh while $55.3 \%$ in Turkey, the second position users use on FB 4 years with $36.9 \%$ in Bangladesh and 32\% in Turkey. Research shows Bangladeshi people have an intention to make more friends on FB, 35.1\% respondents have 1001-2500 friends where in Turkey $34 \%, 15.5 \%$ respondents had 2501-5000 friends in Bangladesh where in Turkey only 4.7\%. 501-1000 is the maximum percentage in Turkey with $35.3 \%$ shows they like to make friends whom they know well and $25.3 \%$ have less than 500 friends on FB. In Bangladesh, 55.5\% users use both Mobile device and PC to access on FB and $40.5 \%$ are Mobile device users. Whereas, in Turkey, $87.3 \%$ users use both Mobile device and $\mathrm{PC}$ to access on FB shows they have available devices to access internet. $36.3 \%$ users use FB 12 hours on daily basis, 28.9\%; 2-3 hours, 22.6\%; More than 3 hours and $12.2 \%$; $0-59$ minutes in Bangladesh. Whereas in Turkey, 39.3\% users use FB 2-3 hours, 29.4\%; 2-3 hours, 17.3\%; More than 3 hours and $14 \%$ use only $0-59$ minutes. 
INTERNATIONAL JOURNAL OF ACADEMIC RESEARCH IN BUSINESS AND SOCIAL SCIENCES

Vol. 9, No. 2, Feb, 2019, E-ISSN: 2222-6990 C 2019 HRMARS

Table 2 and 3: Comparative descriptive statistics of two different cultures buying behavior of Youth Groups on Facebook Advertisement

Table 2: Buying Behavior of Bangladeshi Youth Groups on Facebook Advertisement

\begin{tabular}{|c|c|c|c|}
\hline Statements & $\mathrm{N}$ & Mean & $\begin{array}{l}\text { Std. } \\
\text { Deviation }\end{array}$ \\
\hline 1.I will buy products that are advertised on FB in the near future & 168 & 3.56 & .983 \\
\hline 2.I desire to buy products that are promoted on FB & 168 & 3.44 & 1.025 \\
\hline $\begin{array}{l}\text { 3.Advertisements on FB do not increase purchase intention of } \\
\text { featured brands }\end{array}$ & 168 & 2.39 & .991 \\
\hline 4.Advertisements on FB have a positive influence on my purchase & 168 & 3.77 & 1.114 \\
\hline $\begin{array}{l}5.1 \text { would buy the products that are advertised on FB if I had the } \\
\text { money }\end{array}$ & 168 & 3.73 & 1.181 \\
\hline 6.I do not intend to acquire products that are promoted on FB & 168 & 2.53 & .978 \\
\hline 7.I like to take a chance and purchase items advertised on FB & 168 & 3.60 & .924 \\
\hline $\begin{array}{l}\text { 8.Advertisements on FB have a negative influence on buying } \\
\text { decisions }\end{array}$ & 168 & 2.32 & 1.106 \\
\hline 9.Advertisements on FB make me less loyal to brands & 168 & 2.29 & .987 \\
\hline 10.I use many of the products that are promoted on FB & 168 & 3.21 & 1.127 \\
\hline 11.I share positive advertisements to my FB friends and colleagues & 168 & 3.68 & .980 \\
\hline 12.Information of FB is more reliable than traditional advertising & 168 & 3.35 & 1.067 \\
\hline $\begin{array}{l}\text { 13. There is no difficulty in obtaining information on brands and } \\
\text { products on FB }\end{array}$ & 168 & 3.50 & .935 \\
\hline $\begin{array}{l}\text { 14.Informationon FB is the new electronic word - of - mouth } \\
\text { marketing }\end{array}$ & 168 & 3.89 & .929 \\
\hline $\begin{array}{l}\text { 15. FB advertisements have encouraged me to engage in purchasing } \\
\text { activity }\end{array}$ & 168 & 3.60 & 1.062 \\
\hline 16.I like to purchase new brands advertised on FB before others do & 168 & 3.33 & .995 \\
\hline 17.FB ad offers me a variety of products / items & 168 & 3.65 & .876 \\
\hline $\begin{array}{l}\text { 18.I am satisfied with the amount of information on brands and } \\
\text { products I can attain on FB }\end{array}$ & 168 & 3.38 & 1.025 \\
\hline $\begin{array}{l}\text { 19.I would like to recommend my friends and colleagues to } \\
\text { purchase products advertised on FB }\end{array}$ & 168 & 3.49 & 1.105 \\
\hline
\end{tabular}


INTERNATIONAL JOURNAL OF ACADEMIC RESEARCH IN BUSINESS AND SOCIAL SCIENCES

Vol. 9, No. 2, Feb, 2019, E-ISSN: $2222-6990$ ๑ 2019 HRMARS

Table 3: Buying Behavior of Turkish Youth Groups on Facebook Advertisement

\begin{tabular}{|l|l|l|l|}
\hline Statements & $N$ & Mean & Std. Deviation \\
\hline 1.I will buy products that are advertised on FB in the near future & 150 & 3.63 & 1.120 \\
2.I desire to buy products that are promoted on FB & 150 & 3.78 & 1.152 \\
3.Advertisements on FB do not increase purchase intention of featured & 150 & 1.91 & .854 \\
brands & 150 & 4.03 & 1.087 \\
4.Advertisements on FB have a positive influence on my purchase & 150 & 3.99 & 1.173 \\
5.I would buy the products that are advertised on FB if I had the money & 150 & 2.21 & .964 \\
6.I do not intend to acquire products that are promoted on FB & 150 & 3.49 & .895 \\
7.I like to take a chance and purchase items advertised on FB & 150 & 2.03 & 1.108 \\
8.Advertisements on FB have a negative influence on buying decisions & 150 & 2.19 & 1.019 \\
9.Advertisements on FB make me less loyal to brands & 150 & 3.33 & 1.052 \\
10.I use many of the products that are promoted on FB & 150 & 3.75 & 1.164 \\
11.I share positive advertisements to my FB friends and colleagues & 150 & 3.13 & 1.097 \\
12.Information of FB is more reliable than traditional advertising & & 3.63 & .909 \\
13.There is no difficulty in obtaining information on brands and products & 150 & 3.9 \\
on FB & & 4.37 & 4.164 \\
14.Informationon FB is the new electronic word - of - mouth marketing & 150 & 4.57 & .986 \\
15.FB advertisements have encouraged me to engage in purchasing activity & 150 & 3.57 \\
16.I like to purchase new brands advertised on FB before others do & 150 & 3.54 & 1.040 \\
17.FB ad offers me a variety of products / items & 150 & 3.93 & .928 \\
18.I am satisfied with the amount of information on brands and products I & 150 & 3.76 & 1.001 \\
can attain on FB & & & \\
19.I would like to recommend my friends and colleagues to purchase & 150 & 3.87 & 1.113 \\
products advertised on FB & & \\
\hline
\end{tabular}

Comparative descriptive statistics of two different cultures buying behavior represent the similar findings that the Facebook advertisements positively influence the buying behavior of Bangladeshi and Turkish youth groups.

\section{Factor Analysis}

A factor analysis was useful to indentify the factors and explore how Facebook advertisements influence the buying behavior of two countries consumers i.e. Bangladesh and Turkey. In this study respondents were asked to identify the factors that affect their purchasing behavior through the Facebook advertisements of Bangladesh and Turkey. Based on the review of literature 19 statements have been framed on the five point Likert's scale which ranges from strongly disagree to strongly agree. 
INTERNATIONAL JOURNAL OF ACADEMIC RESEARCH IN BUSINESS AND SOCIAL SCIENCES Vol. 9, No. 2, Feb, 2019, E-ISSN: $2222-6990$ ๑ 2019 HRMARS

Table 4: KMO and Bartlett's Test

\begin{tabular}{|c|c|c|c|}
\hline \multicolumn{2}{|l|}{ Statements } & Bangladesh & Turkey \\
\hline \multicolumn{2}{|c|}{ Kaiser-Meyer-Olkin Measure of Sampling Adequacy. } & .928 & .936 \\
\hline \multirow[t]{3}{*}{ Bartlett's Test of Sphericity } & Approx. Chi-Square & $1.842 \mathrm{E} 3$ & $2.029 \mathrm{E} 3$ \\
\hline & df & 171 & 171 \\
\hline & Sig. & .000 & .000 \\
\hline
\end{tabular}

The most important factors have been identified concerning the respondents' buying behavior of Facebook advertisements using the rotated component matrix analyses and it is based on varimax rotation method. By the way the researchers used the process followed by (RAZU, 2017). It is notably indicated by the Bartlett's test of sphericity that the high correlation exists among the variables and it is showing that the value of chi-square statistics is $1.842 \mathrm{E} 3$ with 171 degrees of freedom, at $5 \%$ significance level for Bangladeshi consumers while the proper chi-square statistics is 2.029E3 with same degrees of freedom and significance level for the Turkish consumers. The value of KMO statistics $(0.928 \& 0.936)$ is also bigger $(>0.5)$ respectively for both of the countries. For this reason factor analysis can be utilized as suitable procedure to examine the data. Therefore, the factor analysis was proved to be the fitting preference for the study. This examination yielded a 2-factor solution for Bangladesh and 4-factor solution for Turkey that explained $58.575 \%$ and $67.590 \%$ of the variance for Bangladesh and Turkey respectively as illustrated in Table 5 . The two major factors for $\mathrm{BD}$ have been identified according to the variables that have higher load under one factor, as (1) Encouraging and motivational factors of FB ads; (2) Negative aspiration of products that are advertised on FB. In case of Turkish consumers, only one variable was found in the factor 4 , so the researchers have included this one variable to the factor 3 and these factors named as (1) Encouraging and motivational factors of FB ads; (2) Influences of FB ads in taking purchase decision; and (3) Negative aspiration of FB products and New electronic promotion. Therefore, giving importance on these factors would enable the marketers to increase brand image in providing advertisements on Facebook and enhance to make right decision.

Table 5: Total Variance Explained

\begin{tabular}{|l|l|l|l|l|l|l|}
\hline \multirow{2}{*}{ Component } & \multicolumn{2}{|l|}{ Initial Eigenvalues of Bangladesh } & \multicolumn{2}{l|}{ Initial Eigenvalues of Turkey } \\
\cline { 2 - 7 } & Total & $\%$ of Variance & Cumulative \% & Total & \% of Variance & $\begin{array}{l}\text { Cumulative } \\
\%\end{array}$ \\
\hline 1 & 9.460 & 49.790 & 49.790 & 9.420 & 49.578 & 49.578 \\
2 & 1.669 & 8.785 & 58.575 & 1.345 & 7.080 & 56.658 \\
3 & & & & 2.077 & 10.931 & 67.590 \\
\hline
\end{tabular}

Note: The value of \% of variance and the initial eigenvalue of component 4 is added to the variance of component 3 as component 3 includes only one variable. 
INTERNATIONAL JOURNAL OF ACADEMIC RESEARCH IN BUSINESS AND SOCIAL SCIENCES Vol. 9, No. 2, Feb, 2019, E-ISSN: $2222-6990$ ๑ 2019 HRMARS

Table 6: Influential Factors of FB Ads on the Buying Behavior of Bangladeshi Consumers

\begin{tabular}{|l|l|l|l|l|}
\hline $\begin{array}{l}\text { Serial } \\
\text { No. }\end{array}$ & Factor Named as & $\begin{array}{l}\text { Initial Eigen } \\
\text { Values }\end{array}$ & $\begin{array}{l}\text { of } \\
\text { Variance }\end{array}$ & $\begin{array}{l}\text { Cumulative } \\
\%\end{array}$ \\
\hline 1 & $\begin{array}{l}\text { Encouraging and motivational factors of FB } \\
\text { ads }\end{array}$ & 9.460 & $49.790 \%$ & $49.790 \%$ \\
\hline 2 & $\begin{array}{l}\text { Negative aspiration of products that are } \\
\text { advertised on FB }\end{array}$ & 1.669 & $8.785 \%$ & $58.575 \%$ \\
\hline
\end{tabular}

Table 7: Influential Factors of FB Ads on the Buying Behavior of Turkey Consumers

\begin{tabular}{|c|c|c|c|c|}
\hline $\begin{array}{l}\text { Serial } \\
\text { No. }\end{array}$ & Factor Named as & $\begin{array}{l}\text { Initial Eigen } \\
\text { Values }\end{array}$ & $\begin{array}{l}\% \text { of } \\
\text { Variance }\end{array}$ & $\begin{array}{l}\text { Cumulative } \\
\%\end{array}$ \\
\hline 1 & $\begin{array}{l}\text { Encouraging and motivational factors of FB } \\
\text { ads }\end{array}$ & 9.420 & $49.578 \%$ & $49.578 \%$ \\
\hline 2 & $\begin{array}{l}\text { Influences of FB ads in taking purchase } \\
\text { decision }\end{array}$ & 1.345 & $7.080 \%$ & $56.658 \%$ \\
\hline 3 & $\begin{array}{l}\text { Negative aspiration of FB products and New } \\
\text { electronic promotion }\end{array}$ & 2.077 & $10.931 \%$ & $67.590 \%$ \\
\hline
\end{tabular}

This study indicates that 'Encouraging and motivational factors of FB ads' is mainly the influential factors elucidating the maximum variance $(49.790 \%)$ in the dependent variable for the Buying Behavior of Bangladeshi Consumers. The sixteen variables contained in this key factor are: Recommend friends and colleagues, More reliable, Engaged in purchasing activity, Take a chance and purchase items advertised on FB, Purchase new brands, no inconvenience in acquiring information on brands and products on FB, More usage facilities, Share positive advertisements, Variety of products / items, Available pocket money, A positive influence on my purchase, New electronic word - of - mouth marketing technique, Buy products in the near future, Varieties of information about different brands and products, Items promoted on FB. The factor loading points for these variables are significantly higher than 0.60 . Hence, policymakers at different business organizations should be more apprehensive about these variables if they aspire to make their FB advertisements more effective for keeping Bangladeshi youth groups satisfied about products and services promoted on facebook.

The second important factor is 'Negative aspiration of products that are advertised on FB', which explains $8.785 \%$ of the variation in the Influences of FB Ads on Bangladeshi Consumers. This factor includes Make less loyal to brands, A negative influence on buying decisions, Not increasing intention to acquire products, Not increasing purchase intention of featured. The factor loading points for four of these variables are also higher than .60 and the negative value of these negative statements indicates the positive influences of FB Ads on Bangladeshi Consumers. 
INTERNATIONAL JOURNAL OF ACADEMIC RESEARCH IN BUSINESS AND SOCIAL SCIENCES

Vol. 9, No. 2, Feb, 2019, E-ISSN: 2222-6990 C 2019 HRMARS

Table 8: Results of Rotated Component Matrix: Influences of FB Ads on Bangladeshi Consumers

\begin{tabular}{|c|c|c|c|}
\hline Factor Name & Variables & $\begin{array}{l}\text { Factor } \\
\text { loading }\end{array}$ & $\begin{array}{l}\text { \% of } \\
\text { variance } \\
\text { explained }\end{array}$ \\
\hline \multirow{15}{*}{$\begin{array}{l}\text { Encouraging and } \\
\text { motivational } \\
\text { factors of FB ads } \\
\text { (Alpha Reliability = } \\
0.948 \text { ) }\end{array}$} & V19 (Recommend friends and colleagues) & .818 & \multirow{15}{*}{$49.790 \%$} \\
\hline & V12 (More reliable) & .769 & \\
\hline & V15 (Engaged in purchasing activity) & .762 & \\
\hline & $\begin{array}{l}\text { V7 (Take a chance and purchase items advertised } \\
\text { on FB) }\end{array}$ & .743 & \\
\hline & V16 (Purchase new brands) & .739 & \\
\hline & $\begin{array}{l}\text { V13 (No difficulty in obtaining information on } \\
\text { brands and products on FB) }\end{array}$ & .733 & \\
\hline & V10 (More usage facilities) & .730 & \\
\hline & V11 (Share positive advertisements) & .719 & \\
\hline & V17 (Variety of products / items) & .686 & \\
\hline & V5 (Available pocket money) & .685 & \\
\hline & V4 (A positive influence on my purchase) & .677 & \\
\hline & $\begin{array}{l}\text { V14 (New electronic word - of - mouth marketing } \\
\text { technique) }\end{array}$ & .673 & \\
\hline & V1 (Buy products in the near future) & .666 & \\
\hline & $\begin{array}{l}\text { V18 (Varieties of information about different } \\
\text { brands and products) }\end{array}$ & .647 & \\
\hline & V2 (Items promoted on FB) & .641 & \\
\hline \multirow[b]{4}{*}{$\begin{array}{l}\text { Negative } \\
\text { aspiration of } \\
\text { products that are } \\
\text { advertised on FB } \\
\text { (Alpha Reliability = } \\
0.723 \text { ) }\end{array}$} & V9 (Make less loyal to brands) & -.789 & \multirow[b]{4}{*}{$8.785 \%$} \\
\hline & V8 (A negative influence on buying decisions) & -.754 & \\
\hline & V6 (Not increasing intention to acquire products) & -.635 & \\
\hline & $\begin{array}{l}\text { V3 (Not increasing purchase intention of } \\
\text { featured brands) }\end{array}$ & -.632 & \\
\hline
\end{tabular}

On the other hand, the result of rotated component matrix of Turkey consumers is not completely similar as of Bangladeshi consumers. This matrix extracted mainly three factors while the previous matrix has only two factors. Here, the first and most influential factor is also 'Encouraging and motivational factors of FB ads' and it is explaining the maximum variance $(49.578 \%)$ in the Buying Behavior of Turkey Consumers. but it includes only seven variables: Engaged in purchasing activity, Recommend friends and colleagues, Purchase new brands, Varieties of information about different brands and products, Share positive advertisements, Variety of products / items, Information on FB is more reliable.

The second most important factor is 'Influences of FB ads in taking purchase decision' explains $7.080 \%$ of variance and includes nine variables - A negative influence on buying decisions, Take a 
INTERNATIONAL JOURNAL OF ACADEMIC RESEARCH IN BUSINESS AND SOCIAL SCIENCES Vol. 9, No. 2, Feb, 2019, E-ISSN: 2222-6990 C 2019 HRMARS

chance and purchase items advertised on FB, Available pocket money, Buy products in the near future, Items promoted on FB, A positive influence on my purchase, Loyal to brands, no inconvenience in acquiring information on brands and products on FB, More usage facilities.

The third influential factor is the 'Negative aspiration of FB products and new electronic promotion' explains $10.931 \%$ of variance. Three variables incorporated in this component are not increasing intention to acquire products, not increasing purchase intention of featured brands, new electronic word - of - mouth marketing technique. The factor loading points of these negative statements are also considerably higher, which shows the significant level of Turkey consumers are positively influenced by the products and services and they have positive intentions to buy the goods advertised on FB.

Table 9: Results of Rotated Component Matrix: Influences of FB Ads on Turkey Consumers

\begin{tabular}{|c|c|c|c|}
\hline Factor Name & Variables & $\begin{array}{l}\text { Factor } \\
\text { loading }\end{array}$ & $\begin{array}{l}\% \\
\text { variance } \\
\text { explained }\end{array}$ \\
\hline \multirow{7}{*}{$\begin{array}{l}\text { Encouraging and } \\
\text { motivational } \\
\text { factors of FB ads } \\
\text { (Alpha Reliability = } \\
0.890 \text { ) }\end{array}$} & V15 (Engaged in purchasing activity) & .815 & \multirow{7}{*}{$49.578 \%$} \\
\hline & V19 (Recommend friends and colleagues) & .758 & \\
\hline & V16 (Purchase new brands) & .745 & \\
\hline & $\begin{array}{l}\text { V18 (Varieties of information about different } \\
\text { brands and products) }\end{array}$ & .740 & \\
\hline & V11 (Share positive advertisements) & .674 & \\
\hline & V17 (Variety of products / items) & .660 & \\
\hline & V12 (Information on FB is more reliable) & .598 & \\
\hline \multirow{9}{*}{$\begin{array}{l}\text { Influences of FB } \\
\text { ads in taking } \\
\text { purchase decision } \\
\text { (Alpha Reliability = } \\
0.645 \text { ) }\end{array}$} & V8 (A negative influence on buying decisions) & -.798 & \multirow{9}{*}{$7.080 \%$} \\
\hline & $\begin{array}{l}\text { V7 (Take a chance and purchase items advertised } \\
\text { on FB) }\end{array}$ & .712 & \\
\hline & V5 (Available pocket money) & .710 & \\
\hline & V1 (Buy products in the near future) & .679 & \\
\hline & V2 (Items promoted on FB) & .654 & \\
\hline & V4 (A positive influence on my purchase) & .608 & \\
\hline & V9 (Loyal to brands) & -.593 & \\
\hline & $\begin{array}{l}\text { V13 (No difficulty in obtaining information on } \\
\text { brands and products on FB) }\end{array}$ & .568 & \\
\hline & V10 (More usage facilities) & .564 & \\
\hline \multirow{3}{*}{$\begin{array}{l}\text { Negative } \\
\text { aspiration of FB } \\
\text { products and New } \\
\text { electronic } \\
\text { promotion(Alpha } \\
\text { Reliability }=0.630 \text { ) }\end{array}$} & V6 (Not increasing intention to acquire products) & .786 & \multirow{3}{*}{$10.931 \%$} \\
\hline & $\begin{array}{l}\text { V3 (Not increasing purchase intention of } \\
\text { featured brands) }\end{array}$ & .534 & \\
\hline & $\begin{array}{l}\text { V14 (New electronic word - of - mouth marketing } \\
\text { technique) }\end{array}$ & .936 & \\
\hline
\end{tabular}


It is noted that the findings of both countries show almost parallel results as the consumers of Bangladesh and Turkey are influenced by similar factors in purchasing products and services advertised on Facebook.

\section{Conclusion}

Facebook is one of the social networking sites for social interaction and has provided advertisers an eminent platform to reach their intended groups. The electronic marketplace has been created due to the advertising on Facebook where physical vicinity is no longer required for exchange to come about. Hence, advertisers should rethink for placing their advertisements on social networking sites, especially on Facebook because it has created straight interaction and correlation between the customers and the advertisers. Many studies have exhibited that youths are the main users of Facebook as soon as the advertisements appear on Facebook. And one of the crucial things is that they use Facebook daily, even they access on Facebook couples of times a day. Research shows that youths are deliberately access on Facebook and their duration to stay there is very impressive number in both countries Bangladesh and Turkey. In addition, youth is the big population in both countries. However, Facebook advertising is one of the cheapest forms of advertising. Even 5 dollars is enough to reach 1000 people. It is too much costly to reach this amount of people in other medium of communications such as radio ads, television commercials, billboards, and other traditional media. Research shows that Influences of Facebook advertisement on the buying behavior of youth groups are positive in Bangladesh and Turkey. Considering the fact, Advertisers can take an initiative to place their ads on Facebook to let their customers know about their product or service. Pointing out that the appealing, fashion-forward and impressive advertisements should be made by the advertisers so that Facebook users, particularly the youths, will not only feel like do business with the products, but rather be a customer of the products. Businesses creating their own Facebook page and placing advertisements on there can reach their intended consumers effectively with low cost and very little time by using this approach. These findings will be more beneficial for the advertisers, advertising agencies, practitioners, and marketers who are responsible to work in the concerned field in designing and placing effective advertising on Facebook to make their consumers more loyal about products and services advertised on this site. Further research can be conducted for exploring the influential factors of Facebook advertisement of multi-countries consumer behavior in taking purchase decision.

\section{References}

Ahmed, A. (2018). The Rohingya: Myanmar's outcasts. Aljazeera.

Mahmood, S. S., Wroe, E., Fuller, A., \& Leaning, J. (2017). The Rohingya people of Myanmar: health, human rights, and identity. The Lancet, 389(10081), 1841-1850. doi:10.1016/s01406736(16)00646-2

Fisher, M. L., \& Salmon, C. (2012). Human nature and pop culture. Review of General Psychology, 16(2), 104-108. doi:10.1037/a0027905

Argan, M., Velioglu, M. N. \& Argan, M. T. (2007). Audience attitudes towards product placement in movies: A case from Turkey. Journal of American Academy of Business, 11, 161-167. 
INTERNATIONAL JOURNAL OF ACADEMIC RESEARCH IN BUSINESS AND SOCIAL SCIENCES

Vol. 9, No. 2, Feb, 2019, E-ISSN: $2222-6990$ ๑ 2019 HRMARS

Armstrong, G. K. \& Harker, P. M. \& Brennan, R.(2009). Marketing-An Introduction. 1st edition. Harlow: Pearson Prentice Hall.

Bueß, J. (2004). Product placement: the analysis of a marketing communication instrument, diplom. de.

Chang, L. \& Krosnick, J. A. (2009). National surveys via RDD telephone interviewing versus the Internet: Comparing sample representativeness and response quality. Public Opinion Quarterly, 73, 641-678.

Chulasiriwongs, C. (2001). Thailand's relations with the new ASEAN members: Solving problems and creating images. Southeast Asian Affairs, 337-354.

Eriksson, L. Wiedersheim-Paul, F.(2011). Att utreda, forska och rapportera, 9.

Bohlin, E., Shaikh, A. A., \& Hanafizadeh, P. (2018). Social Network Banking. International Journal of EBusiness Research, 14(2), 1-13. doi:10.4018/ijebr.2018040101.

Global, G. (2015). Age groups of social media users [Online]. Gemius Global. Available: https://www.gemius.com/agencies-news/age-groups-of-social-media-users.html.

Häckner, J. \& Nyberg, S. (2008). Advertising and media market concentration. Journal of Media Economics, 21, 79-96.

Idris, I. (2017). Rohingya refugee crisis: impact on Bangladeshi politics.

Karrh, J. A., Mckee, K. B. \& Pardun, C. J. (2003). Practitioners' evolving views on product placement effectiveness. Journal of advertising research, 43, 138-149.

Lehu, J.-M. (2007). Branded entertainment: Product placement \& brand strategy in the entertainment business, Kogan Page Publishers.

Manning-Schaffel, V. (2009). Why Brands Have an Eye on Facebook Available from: http://advertiserin-arabia.blogspot.com.tr/2009/05/why-brands-have-eye-on facebook.html.

Meenaghan, T. (1991). The role of sponsorship in the marketing communications mix. International journal of advertising, 10, 35-47.

Murad, M. (2017). Dhaka ranked second in number of active Facebook users. bdnews24.com.

Piskorski, M. J., Eisenmann, T. R., Chen, D. \& Feinstein, B. (2010). Facebook's platforms.

Přikrylová, J. \& Jahodová, H. (2010). Modern marketing communication. Prague: Grada Publishing.

Razu, A. R. (2017). Changing Phenomenon of TV-Serials and Its Impacts on Bangladeshi Society. Perspective. Dhaka, Bangladesh.

Schiffman, L. G. \& Kanuk, L. L. (2004). Consumer behaviour 8 th ed. NY: Prentice-Hall Inc.

Solaja, O. \& Odiaka, S. (2010). Advertisement in the new media gains ground. MarkComm Digest.

Su, S. (2010). Facebook's Spanish-Language Market Marked by Fragmentation, but Promises Opportunity. ADWEEK. USA: ADWEEK.

Wallén, G. (1996). Vetenskapsteori och forskningsmetodik. Lund: Studentlitteratur. Social work, work science and sociology: Växjö University, Socialt arbete-aktuell forskning, vetenskapsteori och forskningsmetodik.

Watch, A. (1992). Burma: Rape, forced labor and religious persecution in Northern Arakan. Asia Watch, 4, 1-25.

Zephoria, J. (2018). The Top 20 Valuable Facebook Statistics [Online]. Now Based in Sunny Sarasota, FL: Zephoria Digital Marketing. Available: https://zephoria.com/top-15-valuable-facebookstatistics 